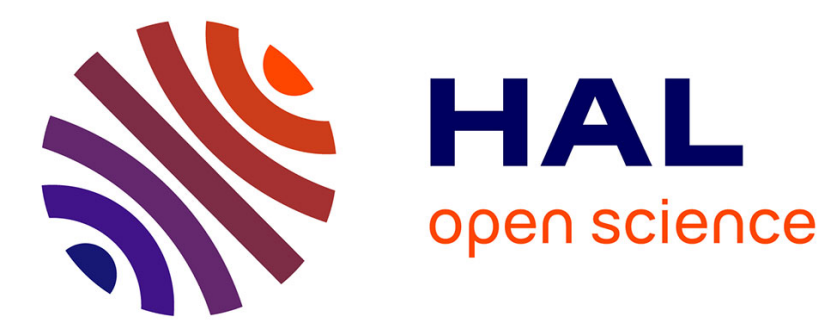

\title{
Efficient Utilization of Higher-Lying Excited States to Trigger Charge-Transfer Events
}

Pierre-Antoine Bouit, Fabian Spänig, Gregory Kuzmanich, Evangelos Krokos, Christian Oelsner, Miguel a. Garcia-Garibay, Juan luis Delgado, Nazario Martín, Dirk m. Guldi

\section{To cite this version:}

Pierre-Antoine Bouit, Fabian Spänig, Gregory Kuzmanich, Evangelos Krokos, Christian Oelsner, et al.. Efficient Utilization of Higher-Lying Excited States to Trigger Charge-Transfer Events. Chemistry - A European Journal, 2010, 16 (31), pp.9638-9645. 10.1002/chem.201001613 hal-01089804

\section{HAL Id: hal-01089804 https://hal-univ-rennes1.archives-ouvertes.fr/hal-01089804}

Submitted on 23 May 2016

HAL is a multi-disciplinary open access archive for the deposit and dissemination of scientific research documents, whether they are published or not. The documents may come from teaching and research institutions in France or abroad, or from public or private research centers.
L'archive ouverte pluridisciplinaire HAL, est destinée au dépôt et à la diffusion de documents scientifiques de niveau recherche, publiés ou non, émanant des établissements d'enseignement et de recherche français ou étrangers, des laboratoires publics ou privés. 


\title{
Efficient Utilization of Higher Lying Excited States to Trigger Charge
}

\section{Transfer Events}

\author{
Pierre-Antoine Bouit, ${ }^{a}$ Fabian Spänig, ${ }^{\mathrm{c}}$ Gregory Kuzmanich, ${ }^{\mathrm{d}}$ Evangelos Krokos, ${ }^{\mathrm{c}}$ Christian \\ Oelsner, ${ }^{\mathrm{c}}$ Miguel A. Garcia Garibay, ${ }^{\mathrm{d} *}$ Juan Luis Delgado, ${ }^{\mathrm{a}, \mathrm{b}}$ Nazario Martín, ${ }^{\mathrm{a}, \mathrm{b}} *$ and Dirk M. \\ Guldi. $^{{ }^{*}}{ }^{*}$
}

(Dedicated to David I. Schuster on the occasion of his $75^{\text {th }}$ birthday)

\begin{abstract}
Several new fullereneheptamethine conjugates absorbing as far as $800 \mathrm{~nm}$ have been synthesized and fully characterized by physicchemical means. In terms of optical and electrochemical characteristics appreciable electronic coupling between both electroactive species is deduced. The latter also reflects the excited state features. To this end, time resolved transient absorption

measurements revealed that photoexcitation is followed by a sequence of charge transfer evolving from higher singlet excited states (i.e., $\mathrm{S}_{2}$ - fast charge transfer) and the lowest singlet excited state (i.e., $\mathrm{S}_{1}-$ slow charge transfer) of the heptamethine cyanine as electron donor to an either covalently linked $\mathrm{C}_{60}$ or $\mathrm{C}_{70}$ as electron acceptor. Finally, charge transfer from photoexcited $\mathrm{C}_{60} / \mathrm{C}_{70}$ completes the
\end{abstract}

charge transfer sequence. The slow internal conversion within the light harvesting heptamethine cyanine and the strong electronic coupling between the individual constituents are particularly beneficial.

Keywords: higher lying excited
states $\cdot$ charge transfer $\cdot$ near
infrared dyes $\cdot$ fullerenes
heptamethine cyanine

\section{Introduction}

Natural systems able to transform efficiently sunlight into chemical energy through the photosynthetic processes, have inspired basic research and developments in the areas of photovoltaics ${ }^{[1]}$ and photocatalysis. ${ }^{[2]}$ Here, "light" reactions, where solar energy is harvested and converted into energy carriers, play a fundamental

[a] Dr. P.-A. Bouit, Dr. J.L. Delgado, Prof. Dr. N. Martín IMDEA-nanociencia, E-28049 Madrid, Spain.

Fax: +34 91394 4103; Tel: +3491394 4227

[b] Dr. J.L. Delgado, Prof. Dr. N. Martín

Departamento de Química Orgánica,Facultad de C. C. Químicas,

Universidad Complutense de Madrid, 28040 Madrid (Spain)

Fax: (+34) 913944103

E-mail: nazmar@quim.ucm.es

Homepage: http://www.ucm.es/info/fullerene

[c] F. Spänig, E. Krokos, C. Oelsner, Prof. Dr. D. M. Guldi Department of Chemistry and Pharmacy \& Interdisciplinary Center of Molecular Materials (ICMM)

Friedrich-Alexander-University Erlangen-Nuremberg

Egerlandstr. 3, 91058 Erlangen, Germany

E-mail: dirk.guldi@chemie.uni-erlangen.de

[d] G. Kuzmanich, Prof. Dr. M. A. Garcia Garibay Department of Chemistry and Biochemistry University of California

Los Angeles, California 90095-1569, USA

E-mail: $\underline{\text { mgg@ @ chem.ucla.edu }}$ role. The successful mimicry of natural photosynthesis - involving the sequence of light harvesting, light funneling, charge separation, and charge shift - mandates the consideration of several aspects, that is, broad light harvesting and efficient charge separation, all combined with slow charge recombination.

For example, the delocalization of charges within the spherical carbon framework of $\mathrm{C}_{60}$ together with its rigid, confined structure of the aromatic $\pi$-sphere offers unique opportunities for stabilizing charged entities. Above all, the small reorganization energies of fullerenes in charge transfer reactions have led to a notable breakthrough in synthetic electron donor acceptor systems by providing accelerated charge separation and decelerated charge recombination. The vast majority of charge transfer reactions commences in the energetically low lying states. Ever since the pioneering work by Hammartström et al. reporting on the electron transfer from higher singlet excited states (i.e., $\mathrm{S}_{2}$ ) of porphyrins to ruthenium (II) complexes, ${ }^{[3]}$ follow-up studies on this topic have been published. ${ }^{[4]}$ In these systems, the large energy gap existing between, for example, higher singlet excited states (i.e., $\mathrm{S}_{2}$ ) and lowest singlet excited state (i.e., $\mathrm{S}_{1}$ ) as well as the relatively long lifetime of $S_{2}$ emerged as key parameters. It is only been very recently that the possibility of designing optoelectronic switches has been forwarded - relying on electron transfer events that are triggered from different excited state precursors in metal-containing porphyrins. $^{[5]}$

On the other hand, dealing with all organic electron donors, only a few examples have been published involving aromatic hydrocarbon containing systems. ${ }^{[6]}$ In this regard, the relationship between structure and charge transfer reactivity will shape solar-toenergy conversion efficiencies, which makes it as important as any other parameter. 
Light harvesting, on the other hand, is rarely addressed, despite its paramount impact on organic photovoltaics. Extending the onset of light harvesting beyond $700 \mathrm{~nm}$ jeopardizes the charge transfer efficiency due to weak driving forces. Such a drawback can be partially compensated by lowering the redox potential of the photoactive components, which is, however, often accompanied by chemical instability. This calls for the necessity of higher lying excited states as a precursor for non-adiabatic charge transfer.

In the context of light harvesting in the infrared part of the solar spectrum, the exceptional optical properties of heptamethine cyanines are a great asset. Their stability is based on the delocalization of a positive charge between two amino end-groups through a rigid, odd-number $\mathrm{C}\left(s p^{2}\right)$ carbon skeleton. ${ }^{[7]}$ The complex electronic structure of heptamethine cyanines prompts to structural inertia and, in turn, to slow structural relaxation / thermalization, especially of higher excited states. ${ }^{[3 \mathrm{~b}-\mathrm{d}, 4,8]}$ All of the aforementioned criteria motivated us to probe them in conjunction with $\mathrm{C}_{60}$ as well as $\mathrm{C}_{70}$ as photo- and redox-active building blocks. Importantly - to the best of our knowledge - heptamethine cyanines covalently linked to fullerenes have never been probed in photoinduced charge transfer reactions neither as photo- nor as redox-active constituent. ${ }^{[9]}$

In this communication, we report on uncommon charge transfer evolving from higher singlet excited states of a heptamethine cyanine as electron donor to an either covalently linked $\mathrm{C}_{60}$ or $\mathrm{C}_{70}$ as electron acceptor. Beneficial is the slow internal conversion within the light harvesting heptamethine and the strong electronic coupling between the individual constituents.

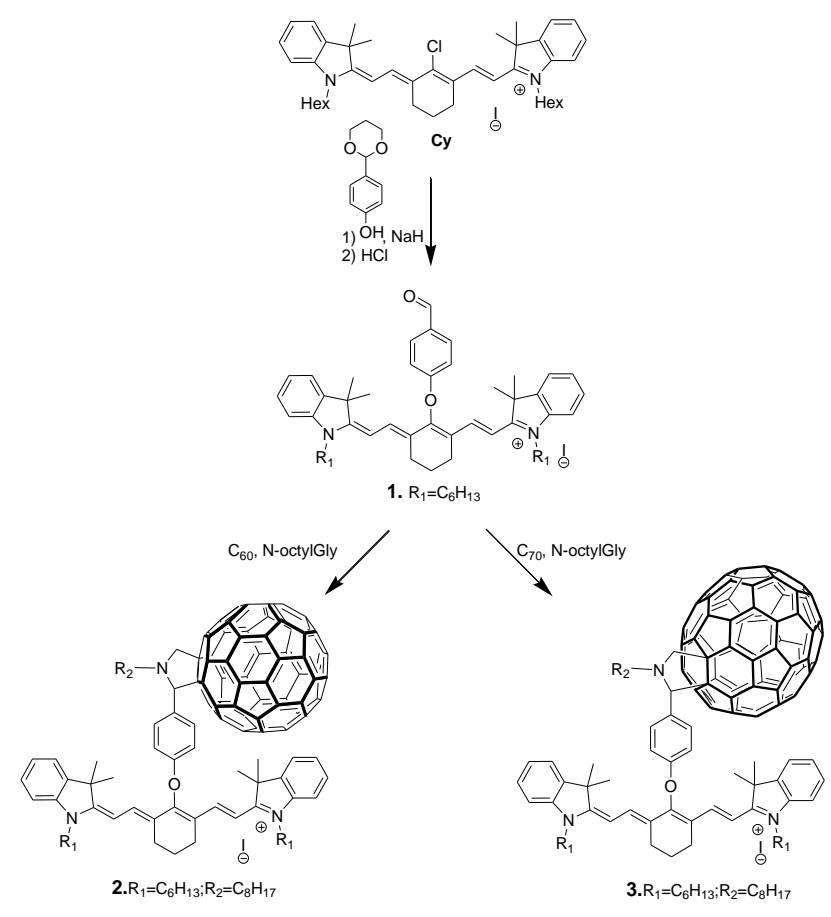

Scheme 1. Synthesis of fullerene-heptamethine conjugates $\mathbf{2}$ and $\mathbf{3}$

Synthesis The synthesis of the electron donor acceptor conjugates 2 and 3 was carried out in two steps starting from previously described heptamethine cyanines $(\mathbf{C y}) .{ }^{[10]}$ To this end, introducing $p$-hydroxybenzaldehyde to the chloro-heptamethine cyanine $(\mathbf{C y})$ was achieved by substitution of the meso-chlorine atom to form 1 (Scheme 1). ${ }^{[8]}$ Then, the reaction of $\mathbf{1}$ with either $\mathrm{C}_{60}$ or $\mathrm{C}_{70}$ in the presence of $N$-octylglycine, ${ }^{[11]}$ afforded $\mathbf{2}$ and $\mathbf{3}$ as deep green solids in $40 \%$ and $30 \%$ yields, respectively. Notably, 3 was obtained and studied as a mixture of isomers due to the multiple possibilities of adding azomethine ylides to $\mathrm{C}_{70} \cdot{ }^{[12]}$ Notably, the presence of various alkyl chains in $\mathbf{2}$ and $\mathbf{3}$ provides reasonable solubility to these compounds in common organic media. The structures of $\mathbf{2}$ and $\mathbf{3}$ were confirmed by ${ }^{1} \mathrm{H}$ and ${ }^{13} \mathrm{C}-\mathrm{NMR}$ and high resolution MS experiments with molecular ion peaks for $2\left([\mathrm{M}+\mathrm{H}]^{+}=1555.6309\right.$ (calcd. $\mathrm{C}_{118} \mathrm{H}_{80} \mathrm{~N}_{3} \mathrm{O}:$ 1554.6296) and $\mathbf{3}[\mathrm{M}+\mathrm{H}]^{+}=1675.6292$ (calcd. $\left.\mathrm{C}_{128} \mathrm{H}_{80} \mathrm{~N}_{3} \mathrm{O}: 1674.6301\right)$ - see Figures S1 - S5 for details.

Optical properties The absorbance of $\mathbf{1}$ maximizes around 782 $\mathrm{nm}$ followed by weaker transitions in the blue region with maxima at 260, 387, and $440 \mathrm{~nm}$ (Figure 1). From this we calculated singlet excited state energies of $\sim 3.0$ and $1.55 \mathrm{eV}$. The spectra of $\mathbf{2}$ and $\mathbf{3}$ almost resemble the sum of the individual spectra, that is, $\mathbf{1}$ and either $\mathrm{C}_{60}$ or $\mathrm{C}_{70}$. The well-known absorption bands of $\mathrm{C}_{60}$ and $\mathrm{C}_{70}$ are discernable at 256,320, as well as $420 \mathrm{~nm}^{[13]}$ and 236, 359, 377, 467 , as well as $525 \mathrm{~nm},{ }^{[12,14]}$ respectively. Evidence for electronic communication between the electron donor (i.e., 1) and the electron acceptors (i.e., $\mathrm{C}_{60}$ and $\mathrm{C}_{70}$ ) came from reduced extinction coefficients of $\mathbf{2}$ and $\mathbf{3}$ when compared to that of $\mathbf{1}$ (Figure 1). 


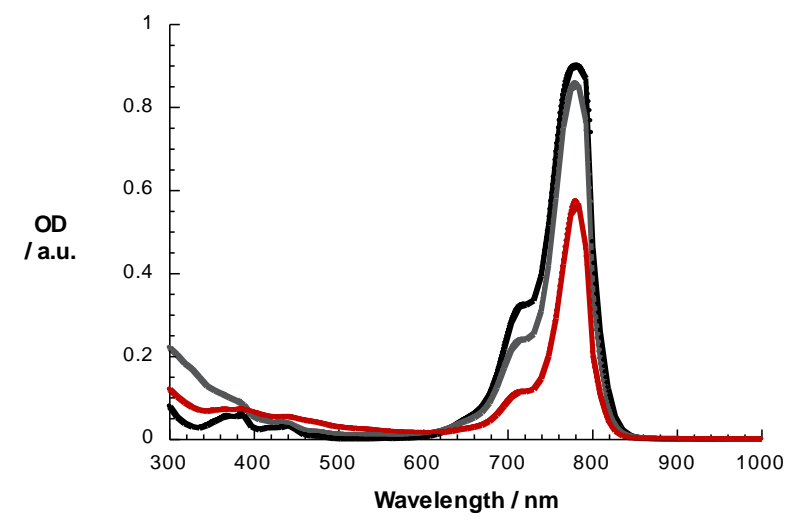

Figure 1. Absorption spectra of $\mathbf{1}$ (black spectrum), $\mathbf{2}$ (grey spectrum), and $\mathbf{3}$ (rec spectrum) $-5.0 \times 10^{-6} \mathrm{M}$ - recorded in dichloromethane

Electrochemistry The electrochemical properties of 1, 2, and $\mathbf{3}$ have been studied in dichloromethane at room temperature by means of cyclic voltammetry (CV) and differential pulse voltammetry (DPV). As described for similar cationic heptamethines, 1 reveals an amphoteric redox character with a completely reversible one-electron reduction process at $-1.02 \mathrm{~V}$ followed by a non reversible reduction process at $-1.94 \mathrm{~V}$ versus ferrocene/ferricenium. ${ }^{[15]}$ One-electron oxidation processes, on the other hand, are noted at $+0.30 \mathrm{~V}-$ fully reversible - and $+0.93 \mathrm{~V}-$ quasi reversible. Additionally, in 2 three reversible one-electron reduction processes - all centered at $\mathrm{C}_{60}$ - were observable at -1.18 , -1.52 , and $-2.07 \mathrm{~V}$ (Figure 2). In $\mathbf{3}$, one-electron reductions of $\mathrm{C}_{70}$ were detected at $-1.20,-1.51$, and $-2.16 \mathrm{~V}$. When compared to pristine $\mathrm{C}_{60}$, these reduction potential values are cathodically shifted. Such a trend has been rationalized on the basis of saturating a double bond of $\mathrm{C}_{60}$, which is known to rise the energy of the LUMO ${ }^{[16,17]}$ In both cases, namely $\mathbf{2}$ and $\mathbf{3}$, the first oxidation of the cyanine was shifted cathodically to $+0.20 \mathrm{~V}$ without, however, affecting the first reduction of $\mathbf{1}-$ see Figures S6 - S7. Consequently, we derive radical ion state pair energies of $1.38 \mathrm{eV}$ (2) and $1.4 \mathrm{eV} \mathrm{(3)} \mathrm{in} \mathrm{dichloromethane.}$

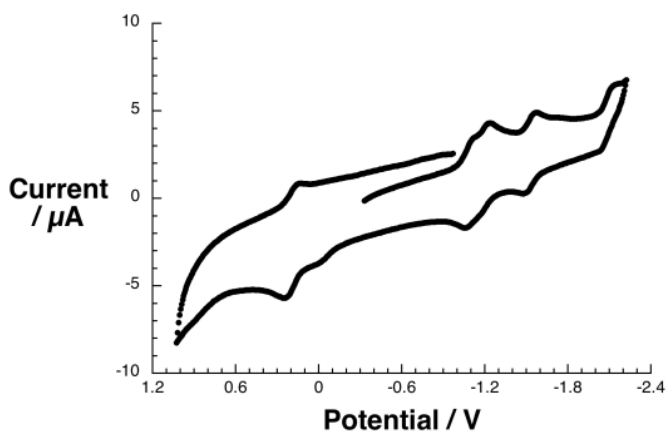

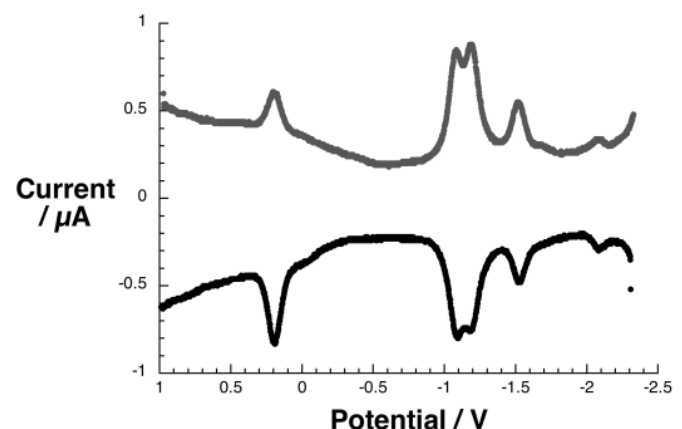

Figure 2. Upper part - cyclic voltammogram of $\mathbf{2}$ recorded in deaerated dichloromethane versus the ferrocene/ferricenium couple $-\mathrm{TBAPF}_{6}$ was employed as supporting electrolyte. Lower part - corresponding differential pulse voltammogram.

Photophysical properties: Next, ultrafast laser flash photolysis experiments were carried out, employing either an excitation wavelength of $387 \mathrm{~nm}$ to photoactivate mainly $\mathrm{C}_{60}$ or $\mathrm{C}_{70}$ or an excitation wavelength of $775 \mathrm{~nm}$ to excite exclusively the cyanine moiety. Excitation of $\mathrm{C}_{60}$ and $\mathrm{C}_{70}$ at $387 \mathrm{~nm}$ populates their singlet excited states with characteristic absorption maxima at $610 / 920^{[11 \mathrm{~b}-}$ ${ }^{18]}$ and $610 / 1360 \mathrm{~nm}$ (Figure S8), ${ }^{[19]}$ respectively. The latter undergo intersystem crossing to the corresponding triplet manifolds with characteristic lifetimes of between 0.7 and $1.4 \mathrm{~ns}$ and characteristic maxima at $700 \mathrm{~nm} \cdot{ }^{[11 \mathrm{~b}, 18,20]}$ The transient absorption spectra upon $387 \mathrm{~nm}$ excitation of $\mathbf{1}$ (Figure S9) in dichloromethane or benzonitrile are dominated by strong ground state bleaching at $800 \mathrm{~nm}$. Directly upon laser excitation the higher singlet excited state features of $\mathbf{1}$ are discernable with maxima at 600,850 and 940 $\mathrm{nm}$, minima at $510,565,715$, and $1255 \mathrm{~nm}$, and broad bleach between 725 and $845 \mathrm{~nm}$. With a lifetime of $2.6 \mathrm{ps}$ these features transform rapidly into those of the lowest singlet excited state with distinct maxima at 515, 560, and $1250 \mathrm{~nm}$ plus distinct minima at 716 and $880 \mathrm{~nm}$. The recovery of the ground state follows afterwards within 1650 ps. On the contrary, when $775 \mathrm{~nm}$ excitation is used (Figure S10) the lowest singlet excited state (1.56 $\mathrm{eV}$ ) is formed instantaneously and rapidly (>0.5 ps) bypassing any higher singlet excited states before converting to the triplet excited state.

When investigating $\mathbf{2}$ and $\mathbf{3}$, instantaneously upon photoexcitation at $387 \mathrm{~nm}$ the higher singlet excited state features of $\mathbf{1}$ are discernable - vide supra. ${ }^{[21]}$ Considering the time window, in which internal conversion and vibrational relaxation occurs for $\mathbf{1}$, the transient characteristics in $\mathbf{2}$ and $\mathbf{3}$ start to transform in benzonitrile into main maxima at 600,1015 , and $1050 \mathrm{~nm}$ as well as $600,850,1015$, and $1300 \mathrm{~nm}^{[11 \mathrm{~b}, 18,22]}$ - the radical ion pair states. Support for this hypothesis was lent from a comparison with spectroelectrochemically and pulse radiolytically generated $\mathbf{1}$ radical dication. In fact, these are in perfect agreement with the transient maxima observed at 600 and $1050 \mathrm{~nm}$. The transient features, on the other hand, at around 1015 and $850 / 1300 \mathrm{~nm}$ are in accordance with previous work by pulse radiolysis assigned to the $\mathrm{C}_{60}$ and $\mathrm{C}_{70}$ radical anions, respectively. ${ }^{[23]}$ Following the charge separation $\left(k_{\mathrm{CS} 1}\right)$, the charge recombination $\left(k_{\mathrm{CR}}\right)$ to recover the ground state sets in with a lifetime of $30 \mathrm{ps}$ in $\mathbf{2}$ (Figure 4) and $45 \mathrm{ps}$ in $\mathbf{3}$ (Figure S11). 

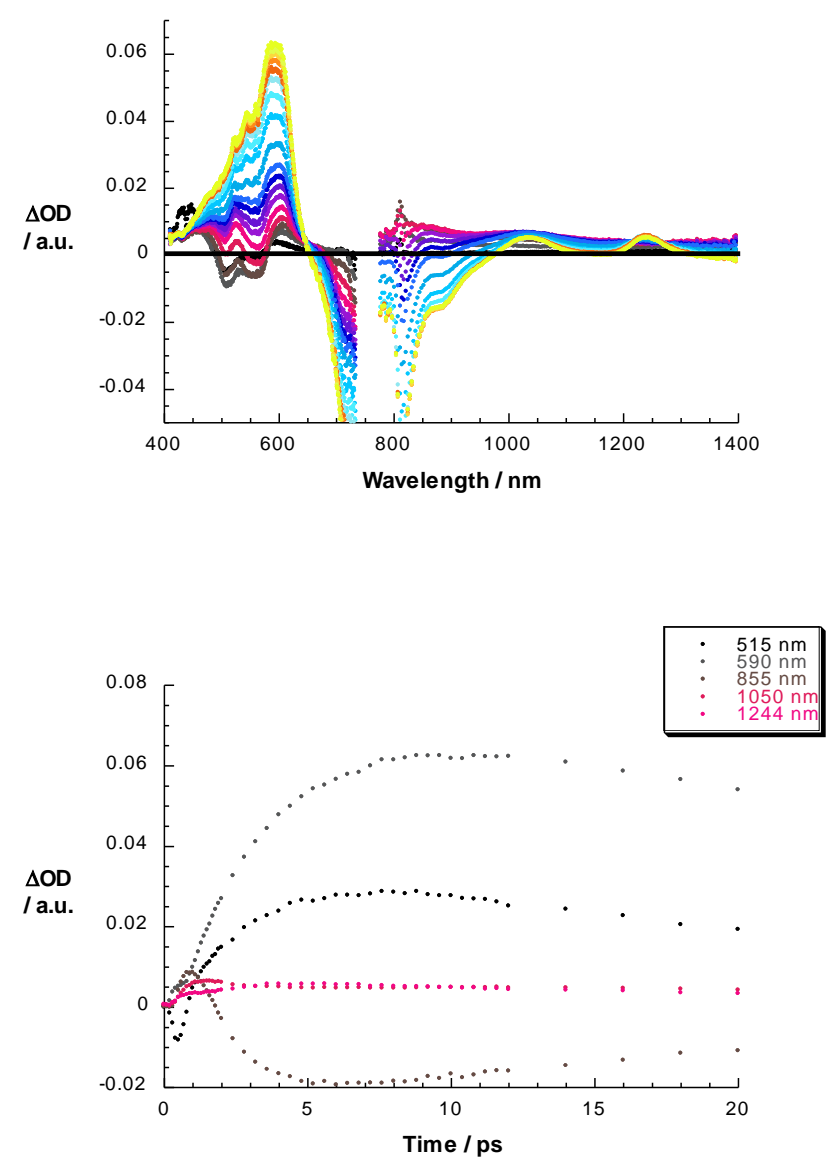

Figure 3. Upper part - differential absorption spectra (visible and near-infrared) obtained upon femtosecond flash photolysis $(387 \mathrm{~nm})$ of $\mathbf{2}$ in benzonitrile with several time delays between 0 and $10 \mathrm{ps}$ at room temperature - time development from black to red to blue to orange and yellow. Lower part - time-absorption profiles of the spectra shown in the upper part at 515, 590, 855, 1050, and $1244 \mathrm{~nm}$ monitoring the competition between formation of the singlet excited state and charge separation as well as charge recombination.

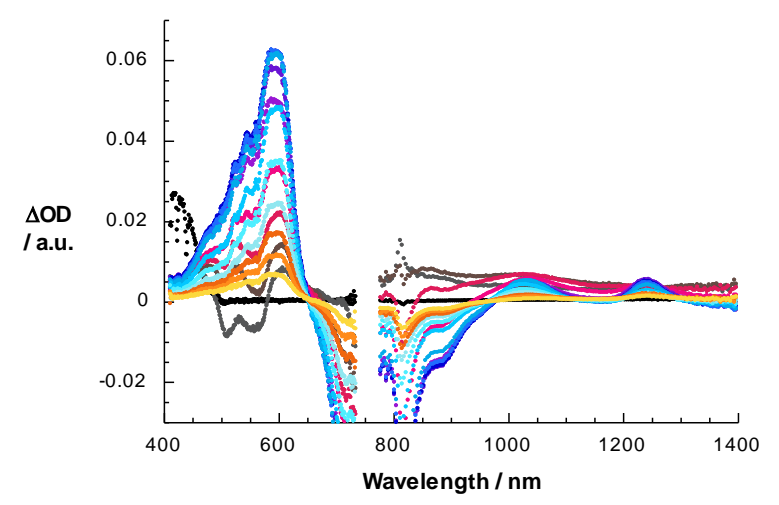

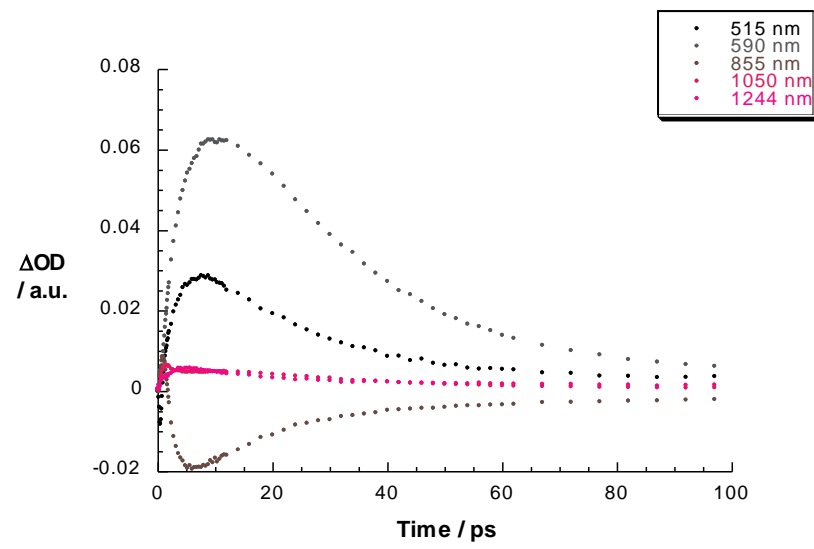

Figure 4. Upper part - differential absorption spectra (visible and near-infrared) obtained upon femtosecond flash photolysis $(387 \mathrm{~nm})$ of $\mathbf{2}$ in benzonitrile with several time delays between 0 and $100 \mathrm{ps}$ at room temperature - time development from black to red to blue to yellow and yellow. Lower part - time-absorption profiles of the spectra shown in the upper part at 515,590, 855, 1050, and $1244 \mathrm{~nm}$ monitoring the charge separation and charge recombination.

Notable is the competition between charge transfer $-k_{\mathrm{CS} 1}-$ (i.e., 3.2 ps) and internal conversion / vibrational relaxation (i.e., $2.6 \mathrm{ps}$ ). The accordingly formed singlet excited states of $\mathbf{1}$ are discernable during the early times of our femtosecond experiments - shoulders at 515 and $560 \mathrm{~nm}$ plus the $1250 \mathrm{~nm}$ maximum. The latter reveals shortened lifetimes of $10(2)$ and 14 ps $(3)-k_{\mathrm{CS} 2}-$ in benzonitrile when compared to the intrinsic lifetime of $\mathbf{1}$ to generate the same radical ion pair state that originated from the higher singlet excited state - Figure 4. By decreasing the solvent polarity the lifetimes for charge separation and charge recombination in $\mathbf{2}$ (Figure S12) are extended to 3.5 and 14 ps, respectively. For $\mathbf{3}$ the lifetimes are 3.5 and 175 ps. Such lifetimes suggest charge separation (i.e., $k_{\mathrm{CS} 1}$, $k_{\mathrm{CS} 2}$ ) and charge recombination dynamics (i.e., $k_{\mathrm{CR}}$ ) that are in the normal and inverted region of the Marcus parabola, respectively. In fact, a correlation between the charge transfer rate (i.e., charge separation and charge recombination) and the free energy change for the underlying reaction reveals a parabolic dependence - as illustrated in Figure 5 - with parameters of the reorganization energy $(0.74 \mathrm{eV})$ and electronic coupling $\left(89 \mathrm{~cm}^{-1}\right)$ closely resembling those seen in recent work involving $\mathrm{C}_{60}$. 


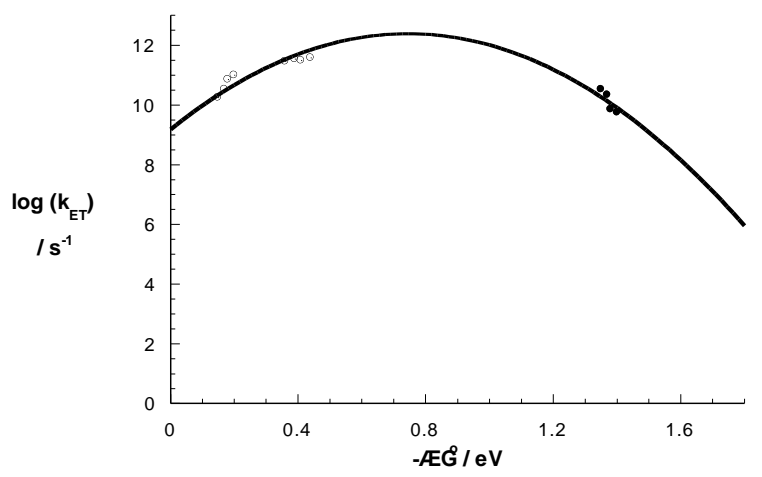

Figure 5. Driving force $\left(-\Delta G^{0}\right)$ dependence of the rate constant for charge separation (open circles) and charge recombination (full circles).

When turning to the red, the singlet excited state features of $\mathrm{C}_{60}$ or $\mathrm{C}_{70}$ are discernable. In the case of $\mathrm{C}_{70}$, these evolve in a region beyond where that of the heptamethine cyanine, namely 1350 to $1600 \mathrm{~nm}$. Unlike what was seen for the reference systems the singlet excited state features are short-lived and transform into those of the radical ion pair states - vide supra. Multiwavelength analyses provide lifetimes in dichloromethane of $9 \mathrm{ps}$ in $\mathbf{2}$ and $11 \mathrm{ps}$ in $\mathbf{3}$.

Upon exciting 2 (Figure 6) and $\mathbf{3}$ at $775 \mathrm{~nm}$ the directly and solely formed singlet excited state features, that is, maxima at 515, 560, and $1250 \mathrm{~nm}$, are in contrast to $\mathbf{1}$ short-lived. In fact, they decay $\left(k_{\mathrm{CS} 2}\right)$ in dichloromethane and benzonitrile with 30 and $10 \mathrm{ps}(\mathbf{2})$ and 21 and $14 \mathrm{ps} \mathrm{(3)}$ to the radical ion pair states. Spectroscopically, the latter comprise for 2 maxima at 600,1015 , and $1050 \mathrm{~nm}$, while $\mathbf{3}$ exhibits maxima at $600,850,1015$, and $1300 \mathrm{~nm}$. Remarkably good is the kinetic agreement - charge separation and charge recombination - between the 387 and $778 \mathrm{~nm}$ experiments.

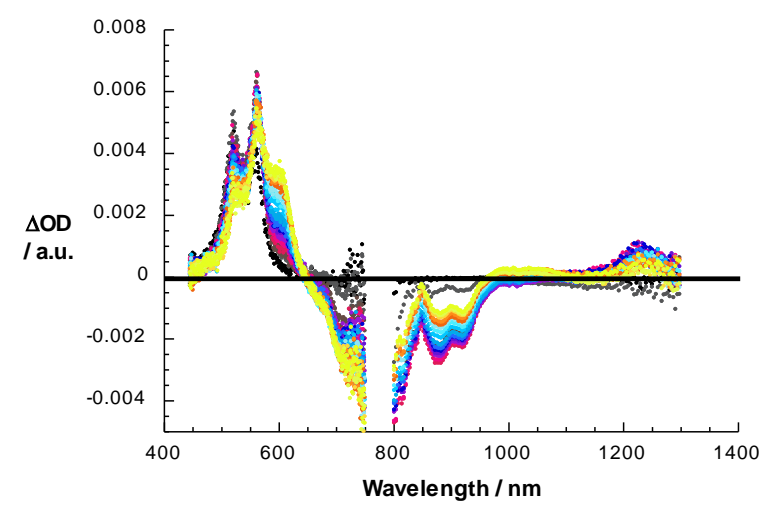

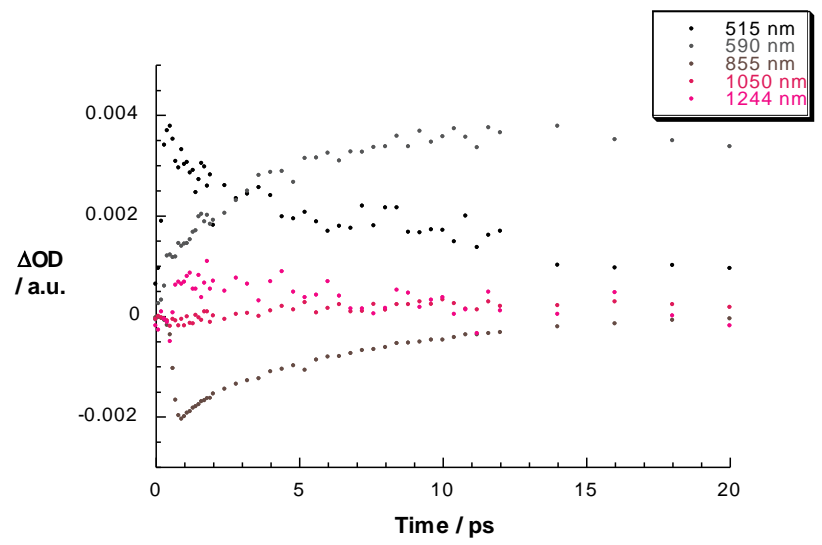

Figure 6. Upper part - differential absorption spectra (visible and near-infrared) obtained upon femtosecond flash photolysis $(778 \mathrm{~nm})$ of $\mathbf{2}$ in benzonitrile with several time delays between 0 and $10 \mathrm{ps}$ at room temperature - time development from black to red to blue to yellow and yellow. Lower part - time-absorption profiles of the spectra shown in the upper part at 515, 590, 855, 1050, and $1244 \mathrm{~nm}$ monitoring the competition between formation of the singlet excited state and charge separation as well as charge recombination.

In summary, photoexciting at $387 \mathrm{~nm}$ in $\mathbf{2}$ or $\mathbf{3}$ with the prompt formation of higher singlet excited states results in two competing processes - Figure 7. On one hand, it is the charge separation that occurs with driving forces around $1.5 \mathrm{eV}$. Key to this pathway, is the close distance between the electron donor and the electron acceptor, which enables strong communication between them. On the other hand, it is the intrinsic deactivation to the lowest singlet excited state subject to a similar driving force. Considering the underlying kinetics, we estimate a branching of approximately 1 to 2 . From the lowest singlet excited state we observe a charge transfer that is about 10 times slower $\left(\left(k_{\mathrm{CS} 2}\right)=30\right.$ ps (2) and 21 ps $\left.(\mathbf{3})\right)$ relative to the charge transfer that finds its origin in the higher singlet excited states $\left(\left(k_{\mathrm{CS} 1}\right)=3.2 \mathrm{ps}(\mathbf{2})\right.$ and $\left.3.5 \mathrm{ps}(\mathbf{3})\right)$. Decisive for the slower kinetics are driving forces of ca. $0.15 \mathrm{eV}$. The higher singlet excited state energies of $1.79\left(\mathrm{C}_{60}\right)$ and $1.76 \mathrm{eV}\left(\mathrm{C}_{70}\right)$ accelerates the charge separation $\left(k_{\mathrm{CS} 3}\right)$ by increasing the driving force to nearly $0.4 \mathrm{eV}$ in dichloromethane with $9 \mathrm{ps}$ (2). It also opens new pathways for the recovery of the ground state, namely energy transfer.

Table 1. Charge separation and charge recombination rate constants for $\mathbf{2}$ and $\mathbf{3}$ in dichloromethane and benzonitrile.

\begin{tabular}{|c|c|c|c|c|c|}
\hline & solvent & $k_{\mathrm{CS} 1}$ & $k_{\mathrm{CS} 2}$ & $k_{\mathrm{CS} 3}$ & $k_{\mathrm{CR}}$ \\
\hline & & $10^{10} \mathrm{~s}^{-1}$ & $10^{10} \mathrm{~s}^{-1}$ & $10^{10} \mathrm{~s}^{-1}$ & $10^{10} \mathrm{~s}^{-1}$ \\
\hline \multirow[t]{2}{*}{2} & dichloromethane & 28.6 & 3.33 & 11.1 & 0.71 \\
\hline & benzonitrile & 31.3 & 10.0 & & 3.33 \\
\hline \multirow[t]{2}{*}{3} & dichloromethane & 28.6 & 4.76 & 9.1 & 0.57 \\
\hline & benzonitrile & 34.5 & 7.14 & & 2.22 \\
\hline
\end{tabular}




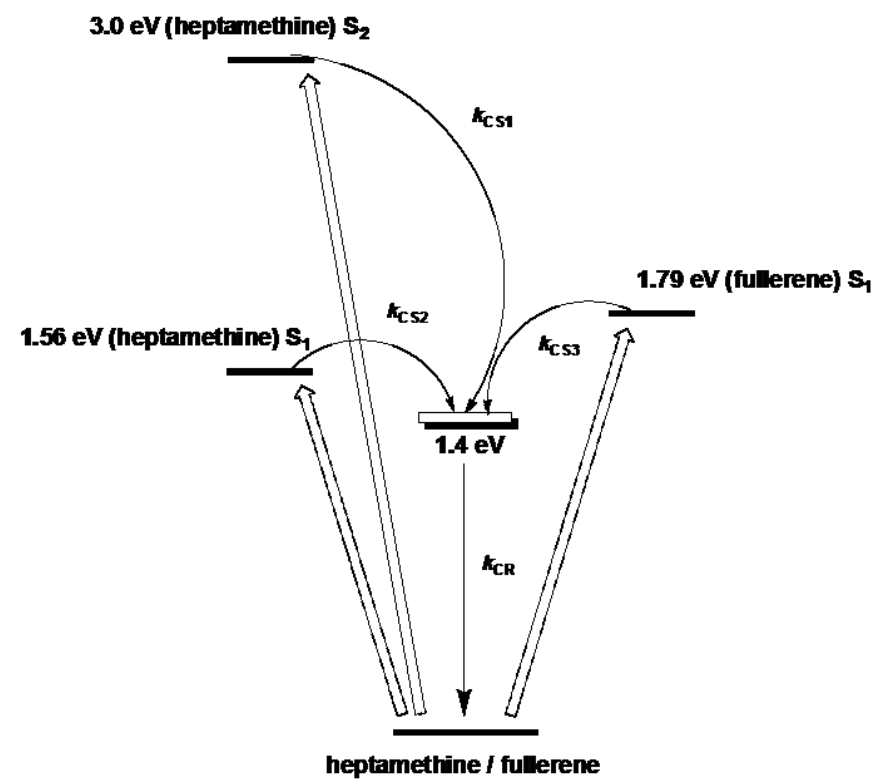

Figure 7. Energy diagram illustrating the different excitation, charge separation $\left(k_{\mathrm{CS} 1}\right.$, $k_{\mathrm{CS} 2}, k_{\mathrm{CS} 3}$ - see for Table 1 for details), and charge recombination $\left(k_{\mathrm{CR}}\right)$ pathways in 2 and 3 .

\section{Conclusions}

The current investigation documents our success in realizing the rarely occurring scenario of a charge transfer commencing with a higher excited state through the tedious choice of electron donor and electron acceptor. In particular, the slow internal deactivation of excited state electron donating heptamethine cyanine and the acceleration of charge transfer reactions by the electron accepting $\mathrm{C}_{60} / \mathrm{C}_{70}$ are crucial requisites. Currently, we are implementing heptamethine cyanines in multicomponent electron donor-acceptor conjugates to slow down charge recombination. From a broader perspective, we hope that this finding will provide the impetus for breakthroughs in near-infrared responsive photovoltaic devices.

\section{Experimental Section}

General synthetic procedures. NMR spectra $\left({ }^{1} \mathrm{H},{ }^{13} \mathrm{C}\right)$ were recorded at room temperature on Bruker DPX $300 \mathrm{MHz}$, Bruker AVIII. $500 \mathrm{MHz}$. Data are listed in parts per million (ppm) and are reported relative to tetramethylsilane $\left({ }^{1} \mathrm{H},{ }^{13} \mathrm{C}\right)$, residual solvent peaks being used as internal standard $\left(\mathrm{CHCl}_{3}{ }^{1} \mathrm{H}: 7.26 \mathrm{ppm},{ }^{13} \mathrm{C}: 77.36 \mathrm{ppm}\right.$, $\mathrm{CDCl}_{3}$ ). High resolution mass spectrometry measurements were performed at the Unidad de Espectrometría de Masas of Universidad Complutense de Madrid. Column chromatography was performed on Merck $60(40-63 \mu \mathrm{m})$ silica. Compound Cy was prepared according to published procedures. ${ }^{5 \mathrm{~b}}$

Synthesis of 1. 4-(1,3-dioxan-2-yl)phenol ( $132 \mathrm{mg}, 0.7 \mathrm{mmol}, 1.1$ eq.) is dissolved in DMF (20 mL) under argon atmosphere. $\mathrm{NaH}(19 \mathrm{mg}, 1.2 \mathrm{eq}$.) is added. After $30 \mathrm{~min}$ of stirring at RT, this solution is added to $\mathbf{C y}$ ( $500 \mathrm{mg}, 0.66 \mathrm{mmol}, 1$ eq.) in DMF ( $20 \mathrm{~mL}$ ) The solution is stirred $6 \mathrm{~h}$ at RT. The solution is then poured into ice and hydrochloric acid $1 \mathrm{M}(200 \mathrm{~mL})$. The resulting green solid is filtrated, dissolved in DCM and washed with water. The solution is then dried with $\mathrm{MgSO}_{4}$ and evaporated. The crude is then dissolved in the minimum amount of DCM and precipitated in diethylether to afford a green solid (380 mg, $68 \%)$. ${ }^{1} \mathrm{H}$ NMR $\left(300 \mathrm{MHz}, \mathrm{CDCl}_{3}\right)$ : $0.9(\mathrm{t}, J=7 \mathrm{~Hz}, 6 \mathrm{H}) ; 1.1-1.5$ $(\mathrm{m}, 14 \mathrm{H}), 1.63(\mathrm{~s}, 12 \mathrm{H}) ; 1.7-1.8(\mathrm{~m}, 4 \mathrm{H}) ; 2.0-2.1(\mathrm{~m}, 2 \mathrm{H}) ; 2.7-2.8(\mathrm{~m}, 2 \mathrm{H}) ; 4.12(\mathrm{t}, J=7$ $\mathrm{Hz}, 4 \mathrm{H}) ; 6.14(\mathrm{~d}, J=15 \mathrm{~Hz}, 2 \mathrm{H}) ; 7.05(\mathrm{~d}, J=8 \mathrm{~Hz}, 2 \mathrm{H}) ; 7.1-7.4(\mathrm{~m}, 8 \mathrm{H}) ; 7.78(\mathrm{~d}, J=$ $15 \mathrm{~Hz}, 2 \mathrm{H}) ; 7.97(\mathrm{~d}, J=8 \mathrm{~Hz}, 2 \mathrm{H}) ; 9.92(\mathrm{~s}, 1 \mathrm{H}) ;{ }^{13} \mathrm{C} \mathrm{NMR}\left(75 \mathrm{MHz}, \mathrm{CDCl}_{3}\right): 4.9 ; 14.0$ $21.0 ; 22.5 ; 24.6 ; 26.7 ; 27.3 ; 27.9 ; 31.4 ; 44.9 ; 49.0 ; 100.7 ; 110.8 ; 115.4 ; 122.0 ; 122.1$; $125.2 ; 128.7 ; 131.3 ; 132.7 ; 141.0 ; 141.2 ; 142.2 ; 162.3 ; 164.0 ; 171.9 ; 190.6$. MS (ESI+): $[\mathrm{M}]^{+}=709.6$ (calcd. for $\mathrm{C}_{49} \mathrm{H}_{61} \mathrm{~N}_{2} \mathrm{O}_{2}: 709.5$ ).

General procedure for the syntheses of 2 and 3: A solution of $\mathrm{C}_{60}(130 \mathrm{mg}, 0.18$ mmol, 3 eq.) and $N$-octylglycine $(11 \mathrm{mg}, 1 \mathrm{eq})$ are refluxed in chlorobenzene $(30 \mathrm{~mL})$ for $30 \mathrm{~min}$ Then, a solution of $1(50 \mathrm{mg}, 1 \mathrm{eq})$ in chlorobenzene $(10 \mathrm{~mL})$ is added dropwise during $2 \mathrm{~h}$. The solution is refluxed $2 \mathrm{~h}$ more, and the solvent is evaporated The crude is purified by column chromatography on silica gel (eluent: toluene then DCM-MeOH: 9-1). The resulting product is dissolved in the minimum amount of DCM and precipitated in pentane to afford a green solid $(40 \mathrm{mg}, 40 \%) .{ }^{1} \mathrm{H} \mathrm{NMR}(300 \mathrm{MHz}$, $\left.\mathrm{CDCl}_{3}\right): 0.9(\mathrm{t}, J=7 \mathrm{~Hz}, 9 \mathrm{H}) ; 1.1-1.5(\mathrm{~m}), 1.7-1.8(\mathrm{~m}) ; 2.0-2.1(\mathrm{~m}, 2 \mathrm{H}) ; 2.4-2.6(\mathrm{~m}$, $1 \mathrm{H}) ; 2.7-2.9(\mathrm{~m}, 4 \mathrm{H}) ; 3.0-3.1(\mathrm{~m}, 1 \mathrm{H}) ; 4.12(\mathrm{t}, J=7 \mathrm{~Hz}, 4 \mathrm{H}) ; 5.00(\mathrm{~s}, 1 \mathrm{H}) ; 5.06(\mathrm{~d}, J=9$ $\mathrm{Hz}, 1 \mathrm{H}) ; 6.10(\mathrm{~d}, J=15 \mathrm{~Hz}, 2 \mathrm{H}) ; 7.05(\mathrm{~d}, J=8 \mathrm{~Hz}, 2 \mathrm{H}) ; 7.1-7.4(\mathrm{~m}, 8 \mathrm{H}) ; 7.85(\mathrm{~d}, J=$ $15 \mathrm{~Hz}, 2 \mathrm{H}) .{ }^{13} \mathrm{C}$ NMR $\left(125 \mathrm{MHz}, \mathrm{CDCl}_{3}\right): 14.4 ; 14.5 ; 15.6 ; 21.1 ; 22.4 ; 22.6 ; 24.5 ; 26.6$; $27.2 ; 27.8 ; 27.9 ; 28.0 ; 28.3 ; 29.4,29.7 ; 31.4 ; 31.9 ; 44.8 ; 48.8 ; 48.9 ; 53.4 ; 65.8 ; 66.6$; $67.3 ; 68.9 ; 76.6 ; 81.9 ; 100.3 ; 110.7 ; 121.9 ; 122.5 ; 125.0 ; 126.4 ; 128.2 ; 128.5 ; 128.7$; $129.0 ; 129.6 ; 131.4 ; 134.2 ; 135.6 ; 136.0 ; 136.3 ; 137.2 ; 139.0 ; 139.8 ; 140.1 ; 140.2$; $140.8 ; 141.2 ; 141.4 ; 141.5 ; 141.6 ; 141.7 ; 141.7 ; 141.8 ; 141.9 ; 142.0 ; 142.0 ; 142.1$ $142.1 ; 142.2 ; 142.2 ; 142.3 ; 142.5 ; 142.5 ; 142.6 ; 142.7 ; 143.0 ; 143.1 ; 144.1 ; 144.3$; $144.4 ; 144.7 ; 144.9 ; 145.0 ; 142.1 ; 145.3 ; 142.3 ; 145.3 ; 145.4 ; 145.5 ; 145.7 ; 145.8$ $145.9 ; 146.0 ; 146.0 ; 146.1 ; 146.1 ; 146.2 ; 146.2 ; 146.3 ; 146.4 ; 146.5 ; 147.2 ; 147.3$; $153.3 ; 153.4 ; 154.1 ; 156.6 ; 159.4 ; 163.5 ; 171.6 ;$ HRMS (MALDI+): $[\mathrm{M}+\mathrm{H}]^{+}=$ 1555.6309 (calcd. for $\mathrm{C}_{118} \mathrm{H}_{80} \mathrm{~N}_{3} \mathrm{O}:$ : 1554.6296).

Compound 3 was synthesized using the same methodology, using $\mathrm{C}_{70}$ as starting material to afford a green solid (30\%). HRMS (MALDI+): $[\mathrm{M}+\mathrm{H}]^{+}=1675.6292$ (calcd for $\mathrm{C}_{128} \mathrm{H}_{80} \mathrm{~N}_{3} \mathrm{O}:$ : 1674.6301).

Electrochemistry. Electrochemical experiments were carried out using a Princeton Applied Research Potentiostat/Galvanostat PAR 263A. Cyclic voltammetry, differential pulse voltammetry and square wave voltammetry were performed in a three electrode cell with a platinum wire as counter electrode, a glassy carbon disk as working electrode $(\varnothing=2 \mathrm{~mm})$ versus a silver wire as reference electrode; ferrocene is applied as an internal standard and a $0.1 \mathrm{M}$ solution of $(t-\mathrm{Bu})_{4} \mathrm{NBF}_{4}$ as the supporting electrolyte. All experiments were performed under inert gas atmosphere and a compound concentration of $0.2 \mathrm{mM}$.

Spectroelectrochemistry: Spectroelectrochemical experiments were carried out using HEKA Elektronik Potentiostat/Galvanostat PG284 and a SPECORD S600 Analytic Jena Spectrophotometer. The measurements were performed in a homemade three neck cell $(\sim 0.3 \mathrm{~cm})$ with a platinum gauze as working electrode, a platinum wire as counter electrode versus a silver wire under Argon atmosphere. Tetra-n-butylammonium hexafluorophosphate $\left(\mathrm{Bu}_{4} \mathrm{NPF}_{6}-0.2 \mathrm{M}\right)$ was used as supporting.

Photophysics. Steady State Fluorescence Spectroscopy: Horiba Jobin Yvon Fluoromax 3 spectrophotometer; in deaerated solution at room temperature $(298 \mathrm{~K})$ in a 1 to $1 \mathrm{~cm}$ quartz cuvette. All spectra were corrected for the instrument response. The monitoring wavelength was corresponding to the maximum of the emission band. Time Resolved Fluorescence: The fluorescence lifetime measurements were performed via time correlated single photon counting (TCSPC) by a FluoroLog-3 in T-configuration (HORIBA-JOBIN YVON) including a MCP detector (R3809U-58). Fluorescence lifetimes were measured at the emission maximum at room temperature in deaerated solution in a 1 to $1 \mathrm{~cm}$ quartz cuvette. fs-Transient Absorption Spectroscopy: Femtosecond transient absorption studies were performed with 775 and $387 \mathrm{~nm}$ laser pulses $(1 \mathrm{kHz}, 150 \mathrm{fs}$ pulse width, $200 \mathrm{~nJ})$ from an amplified Ti/sapphire laser system (Model CPA 2101, Clark-MXR Inc. - output $775 \mathrm{~nm}$ ). The transient absorption pump probe spectrometer (TAPPS) Helios from Ultrafast systems is referred to as a two-beam setup, where the pump pulse is used as excitation source for transient species and the delay of the probe pulse is exactly controlled by an optical delay rail. As probe (white light continuum), a small fraction of pulses stemming from the CPA laser system was focused by a $50 \mathrm{~mm}$ lens into a $3-\mathrm{mm}$ thick sapphire disc. The transient spectra were recorded using fresh oxygen free solutions in each laser excitation. All experiments were performed at $298 \mathrm{~K}$ in a $2 \mathrm{~mm}$ quartz cuvette. Pulse Radiolysis: Pulse radiolysis experiments were performed using $50 \mathrm{~ns}$ pulses of $15 \mathrm{MeV}$ electrons from a linear electron accelerator (LINAC). Dosimetry was based on the oxidation of $\mathrm{SCN}^{-}$to $(\mathrm{SCN})_{2}{ }^{--}$which in aqueous, $\mathrm{N}_{2} \mathrm{O}$-saturated solution takes place with $\mathrm{G} \approx 6$ ( $\mathrm{G}$ denotes the number of species per $100 \mathrm{eV}$, or the approximate $\mu \mathrm{M}$ concentration per $10 \mathrm{~J}$ absorbed energy). The radical concentration generated per pulse was varied between (13) $\times 10^{-6} \mathrm{M}$.

\section{Acknowledgements}

The Deutsche Forschungsgemeinschaft (Grant SFB 583), Cluster of Excellence "Engineering of Advanced Materials", $\mathrm{FCI}<$ and Office of Basic Energy Sciences of the US Department of Energy are gratefully acknowledged. M.A.G.-G and G.K. acknowledge NSF IGERT: Materials Creation Training Program (MCTP) - DGE0654431 and grant NSF-CHE 0844455. This work has been supported by the European Science Foundation (SOHYD, MAT2006-28170-E), the MEC of Spain (CT2008-00795/BQU, and 
Consolider-Ingenio 2010C-07-25200, Nanociencia Molecular) and Comunidad de Madrid (MADRISOLAR-2, S2009/PPQ-1533). J.L.D. thanks the MICINN of Spain for a Ramón y Cajal Fellowship, co-financed by the EU Social Funds. P.A.B. thanks IMDEANanociencia for a postdoctoral research grant.

[1] For some very recent special issues, see: (a) Special issue on "Organic Photovoltaics", J.-L. Bredas, J. R. Durrant, eds. Acc. Chem., Res. 2009, 42, 1689; (b) Special issue on "Renewable Energy", D. Nocera, D. M. Guldi, eds. Chem. Soc. Rev 2009, 38, 1; c) B. O'Regan, M. Grätzel, Nature 1991, 353, 737; d) S. Wenger, P.-A. Bouit,Q. Chen, J. Teuscher, D. Di Censo, R. HumphryBaker, J. E. Moser, J.L Delgado, N. Martín, S. M. Zakeeruddin, M. Grätzel, J Am. Chem. Soc. 2010, 132, 5164. e) S. Gunes, H. Neugebauer, N. S. Sariciftci, Chem. Rev. 2007, 107, 1324; f) B. C. Thompson, J. M. J. Frechet, Angew. Chem. Int. Ed. 2008, 47, 58; g) J. L. Delgado, P.-A. Bouit, S. Filippone, M.A. Herranz, N. Martín, Chem. Commun. 2010, DOI: 10.1039/c003088k; e) I. Riedel, E. von Hauff, J. Parisi, N. Martín, F. Giacalone V. Diakonov, Adv. Funct. Mater. 2005, $15,1979$.

[2] a) N. Armaroli, V. Balzani, Angew. Chem. Int. Ed. 2007, 46, 52; A. Fihri, V. Artero, M. Razavet, C. Baffert, W. Leibl, M. Fontecave, M. Angew. Chem., Int. Ed., 2008, 47, 564.

[ 3 ] D. LeGourrierec, M. Andersson, J. Davidsson, E. Mukhtar, L. Sun, L. Hammarstrom, J. Phys. Chem. A 1999, 103, 557.

[4] a) N. Mataga, H. Chosrowjan, Y. Shibata, N. Yoshida, A. Osuka, T. Kikuzawa, T. Okada, J. Am. Chem. Soc. 2001, 123, 12422; b) T. Kesti, N. Tkachenko, H. Yamada, H. Imahori, S. Fukuzumi, H. Lemmetyinen, Photochem. Photobiol. Sci. 2003, 2, 251; c) J. Petersson, M. Eklund, J. Davidsson, L. Hammarström, J. Am. Chem. Soc. 2009, 131, 7940.

[5] S. Wallin, C. Monnereau, E. Blart, J.-R. Gankou, Fabrice Odobel, Leif Hammarström, J. Phys. Chem A 2010, 114, 1709.

[6] a) P.-A. Muller, E. Vauthey, J. Phys. Chem. A 2001, 105, 5994; b) M. Sakamoto, X. Cai, M. Hara, M. Fujitsuka, T. Majima, J. Am. Chem. Soc. 2004, 126, 9709.

[7] a) R. S. Lepkowicz, O. V. Przhonska, J. M. Hales, J. Fu, D. J. Hagan, E. W. Van Stryland, M. V. Bondar, Y. L. Slominsky, A. D. Kachkovski, Chem. Phys. 2004, 305, 259. b) P.-A. Bouit, C. Aronica, L. Toupet, B. Le Guennic, C. Andraud, O. Maury J. Am. Chem. Soc., 2010, 132, 4328.

[8] a) R. S. H. Liu, A. E. Asato, J. Photochem. Photobiol. C 2003, 4, 179; b) N. Mataga, S. Taniguchi, H. Chosrowjan, A. Osuka, N. Yoshida, Photochem Photobiol. Sci. 2003, 2, 493; c) M. Sakamoto, X. Cai, M. Hara, S. Tojo, M. Fujitsuka, T. Majima, J. Phys. Chem. A 2004, 108, 10941; d) M. Kubo, Y. Mori, M. Otani, M. Murakami, Y. Ishibashi, M. Yasuda, K. Hosomizu, H. Miyasaka, H. Imahori, S. Nakashima, J. Phys. Chem. A 2007, 111, 5136.

[9] For example of systems with smaller trimethine cyanine and $\mathrm{C}_{60}$ showing weak photovoltaic properties, see: F. Meng, J. Hua, K. Chen, H. Tian, L. Zuppiroli, F. Nuesch, J. Mater. Chem. 2005, 15, 979.

[10] a) N. Narayan, G. J. Patonay, J. Org. Chem. 1995, 60, 239; b) P.-A. Bouit, G. Wetzel, G. Berginc, L. Toupet, P. Feneyrou, Y. Bretonnière, O. Maury, C. Andraud, Chem. Mater. 2007, 19, 5325.

[11]a) M. Maggini, G. Scorrano, M. Prato, J. Am. Chem. Soc. 1993, 115, 9798; b) M. Prato, M. Maggini, Acc. Chem. Res. 1998, 31, 519; c) N. Tagmatarchis, M. Prato, Synlett 2003, 768 .

[12] a) A. Hirsch, M. Brettreich, in Fullerenes, Wiley-VCH, Weinheim, Germany, 2005. b) J.L. Delgado, E. Espíldora, M. Liedtke, A. Sperlich, D. Rauh, A. Baumann, C. Deibel, V. Dyakonov, N. Martín, Chem. Eur. J., 2009, 15, 13474.

[13] a) S. Leach, M. Vervloet, A. Desprès, F. Bréheret, J. P. Hare, T. J. Dennis, H. W Kroto, R. Taylor, D. R. M. Walton, Chem. Phys. 1992, 160, 451; b) D. M. Guldi, K.-D. Asmus, J. Phys. Chem. A 1997, 101, 1472.

[14] H. Ajie, M. M. Alvarez, S. J. Anz, R. D. Beck, F. Diederich, F. K., D. R. Huffman, W. Krätschmer, Y. Rubin, K. E. Schriver, D. Sensharma, R. L. Whetten, J. Phys. Chem. A 1990, 94, 8630.

[15] P.-A. Bouit, D. Rauh, S. Neugebauer, J. L. Delgado, E. Di Piazza, S. Rigaut, O. Maury, C. Andraud, V. Dyakonov, N. Martín, Org. Lett. 2009, 11, 4806.

[16] L. Echegoyen, and L.E. Echegoyen, Acc. Chem. Res. 1998, 31, 593.

[17] a) N. Martín, L. Sanchez, B. Illescas, and I. Perez, Chem. Rev. 1998, 98, 2527. b) N. Martín, Chem. Commun. 2006, 2093. c) N. Martin, L. Sanchez, M. A Herranz, B. M. Illescas, D. M. Guldi, Acc. Chem. Res. 2007, 40, 1015; d) F. Giacalone, J. L. Segura, N. Martin, N.; D. M. Guldi, J. Am. Chem.Soc. 2004, 126, 5340; e) M. A. Herranz, N. Martin, S. Campidelli, M. Prato, G. Brehm, D M. Guldi, Angew. Chem. Int. Ed. 2006, 45, 4478; f) M. Wielopolski, C. Atienza, T. Clark, D. M. Guldi, N. Martin, Chem. Eur. J. 2008, 14, 6379. g) S. S Gayathri, M. Wielopolski, E. M. Perez, F. Fernandez, G.; L. Sanchez, R. Viruela, E. Orti, E.; D. M. Guldi, N. Martin, N. Angew. Chem., Int. Ed. 2009, 48, 815; h) A. Molina-Ontoria, G. Fernandez, M. Wielopolski, C. Atienza, L. Sanchez, A Gouloumis, T. Clark, N. Martin, N. ; D. M. Guldi, J. Am. Chem. Soc 2009, 131 , 12218. i) B. M. Illescas, J. Santos, M. Wielopolski, C. M. Atienza, N. Martin, D. M. Guldi, Chem. Commun. 2009, 5374.

[18] D. M. Guldi, F. Hauke, A. Hirsch, Res. Chem. Intermed. 2002, $28,817$.

[19] C. S. Foote, Top. Curr. Chem. 1994, 169, 347.

[20] M.R. Fraelich, R. B. Weisman, J. Phys. Chem. 1993, 97, 11145.

[21] Approximate absorption ratio between $\mathrm{C}_{60} / \mathrm{C}_{70}$ and the heptamethine cyanine is 9:1.

[22] C. A. Reed, R. D. Bolskar, Chem. Rev. 2000, 100, 1075.

[23] G. H. Sarova, U. Hartnagel, D. Balbinot, S. Sali, N. Jux, A. Hirsch, D. M. Guldi, Chem. Eur. J. 2008, 14, 3137. 